Tashev, Blagovest. A la búsqueda de la seguridad: la política de seguridad búlgara en transición.

\title{
IN SEARCH OF SECURITY: BULGARIA'S SECURITY POLICY IN TRANSITION
}

\author{
BLAGOVEST TASHEV *
}

\begin{abstract}
After the collapse of communism, a new strategic thinking in Bulgaria emerged only slowly. The relatively sluggish pace of the process is reflected in the late beginnings of real security and defense reform. Thus, until 1998 security sector reform was not guided by a vision and principles agreed upon by the political elite and the society at large. Political consensus on security policies emerged only in 2000. In the last several years Bulgaria's transition has been guided by its goal of achieving membership in NATO and the European Union. The content of its foreign and security policy, too, has been guided and determined by the two Euro-Atlantic institutions. Now that membership in both organizations seems a matter of time, along with continuing the policies designed to prepare the country for accession, Bulgaria faces the challenge of formulating its security policy for the long run as a member-state. It appears that Bulgaria is going to face difficulties in formulating and applying new security policies in the framework of NATO and in the new security environment.
\end{abstract}

* Director del Programa de Estudios de Seguridad del George C Marshall Association-Bulgaria y Prof. Adjunto en el Depto. de Ciencia Política en la Universidad de Sofia "St Kliment Ohridski" 
Tashev, Blagovest. A la búsqueda de la seguridad: la política de seguridad búlgara en transición.

\title{
A LA BÚSQUEDA DE LA SEGURIDAD: LA POLÍTICA DE SEGURIDAD BÚLGARA EN TRANSICIÓN
}

\author{
BLAGOVEST TASHEV*
}

\section{RESUMEN}

Después del colapso del comunismo, ha emergido paulatinamente en Bulgaria un nuevo pensamiento estratégico. El lento devenir de este proceso quedó reflejado en la reforma real de la seguridad y la defensa. Así, hasta 1998 el sector de la seguridad no estuvo guiado por una visión y unos principios coincidentes con la elite política y la sociedad civil. No fue hasta el año 2000 cuando tuvo lugar el consenso político sobre las políticas de seguridad. En los últimos años, la transición búlgara se ha guiado por el objetivo de conseguir ser miembro de la OTAN y de la Unión Europea. También el contenido de sus políticas de seguridad y defensa han estado determinadas por estas dos instituciones. Ahora que el ingreso en ambas es sólo una cuestión de tiempo, acompañada de la continuidad de las políticas diseñadas para preparar su adhesión, Bulgaria se enfrenta al reto de formular su política de seguridad en la carrera hacia la adhesión. Parece que Bulgaria se enfrenta a dificultades en la formulación y aplicación de las nuevas políticas de seguridad dentro del marco de la OTAN y en el nuevo contexto de seguridad mundial.

* Director del Programa de Estudios de Seguridad del George C Marshall Association-Bulgaria y Prof. Adjunto en el Depto. de Ciencia Política en la Universidad de Sofia "St Kliment Ohridski" 
Tashev, Blagovest. A la búsqueda de la seguridad: la política de seguridad búlgara en transición.

\section{INTRODUCTION}

In the last several years Bulgaria's transition has been guided by its goal of achieving membership in NATO and the European Union. The content of its foreign and security policy, too, has been guided and determined by the two Euro-Atlantic institutions. Now that membership in both organizations seems a matter of time, along with continuing the policies designed to prepare the country for accession, Bulgaria faces the challenge of formulating its security policy for the long run as a member-state. Accordingly, policy decision-makers are about to embark on planning for national security needs within the framework of the Euro-Atlantic institutional space, a process which will to a great extent determine Bulgaria's role in the new security environment. If the past thirteen years are any indication, Bulgaria is about to face hard times in this process.

After the collapse of communism, a new strategic thinking in Bulgaria emerged only slowly. The relatively sluggish pace of the process is reflected in the late beginnings of real security and defense reform. Thus, until 1998 security sector reform was not guided by a vision and principles agreed upon by the political elite and the society at large. It must be noted that only in the last three years did the Bulgarian political elite reach a basic consensus on the Euro-Atlantic direction of Bulgarian foreign policy (especially regarding NATO). Not surprisingly, lacking such a consensus in the early transition period, Bulgarian was unable to implement a comprehensive reform in its security sector, including in defense capabilities planning.

The paper provides an overview of the slowly emerging political consensus on Bulgaria's security policy and the evolution of national strategic thinking. It also points out to some of the future challenges to the country's search of security in the context of integration in the Euro-Atlantic community.

\section{SEEKING SECURITY AFTER THE END OF COMMUNISM}

The end of Soviet domination in Eastern Europe presented Bulgaria with fundamentally different security challenges. Bulgaria's entire security arrangement was based on the assumption that the Warsaw Pact, and the Soviet Union in particular, would provide unconditional assistance in the event of military conflict. Not surprisingly, the Bulgarian leadership was initially reluctant to let the Warsaw Pact go. Very few politicians, notably the Bulgarian President Zhelyu Zhelev, from early on, argued that the Pact was already a political corpse and insisted on closer ties with the West.i Zhelev made several visits to the West, including Western Europe, the United States and Japan in 1990-91 to demonstrate the country's reorientation away from Moscow. While the governments in the first two years after 1989 were broadly supportive of this reorientation, they had a hard time contemplating an alternative to the existing security arrangements in a new security environment. Thus Bulgaria did not initially consider the unilateral dissolution of the Warsaw Pact as a valuable option.ii

When the end of the Warsaw Pact became inevitable in 1991, Bulgaria was at a loss to produce an alternative security policy. While acquiescing to the loss of traditional security guarantees, Sofia attempted to ensure national security by 
Tashev, Blagovest. A la búsqueda de la seguridad: la política de seguridad búlgara en transición.

enhancing national military power, improving relations with neighboring states and nurturing a new, more equal relationship with the Soviet Union.iii Although the government recognized that the new approach required good relations with NATO, it doubted Bulgaria would become a member of the Alliance.iv

The loss of the traditional security framework which guaranteed Bulgaria's security in the context of fundamental political, social and economic transformation in the country coincided with the emergence of acute regional security challenges. The beginning of Yugoslavia's disintegration and the accompanying civil wars presented the country with unfamiliar threats and risks to which the leadership had no readily available responses. The Bulgarian leadership faced the necessity of formulating new policies and strategies to address the new challenges in a completely new international environment.

The conflicts of Yugoslavia's disintegration involved, among others, Serbia, a state with which Bulgaria had a long history of rivalry, and Macedonia, a country which Balkan states have traditionally sought to possess or dominate.v Sofia feared that the conflict might spill over and engulf the entire region.vi Feeling extremely vulnerable, Bulgaria's policy, until at least 1996, of addressing the likelihood of a wider military conflict was to try to persuade its Balkan neighbors to avoid any involvement in the Yugoslav conflict. This policy explains why Sofia was the last state among the associated members of the EU to provide troops to various peacekeeping operations in the region. It considered such involvement risky and exacerbating conflicts among Balkan states.vii Accordingly, Bulgaria was the first state to recognize Macedonia's independence in 1992, thus trying to prevent the repeat of past attempts by various Balkan states to dominate the area. The growing international isolation of rump Yugoslavia and Bulgaria's commitment to observe political, economic, and military sanctions against Belgrade denied Sofia opportunities to work with Serbia on any of the outstanding issues between the two countries and, in general, rendered impotent any Bulgarian attempts to affect developments in this part of the region.

The disintegration of the Warsaw Pact left Bulgaria alone to face Greece and Turkey, two states Bulgaria was supposed to confront militarily in the event of war during the Cold War. Without external security guarantees, Sofia became increasingly concerned about military imbalances in the region. These concerns became more resilient as, in accordance with the Conventional Forces in Europe Treaty, excess weapons from NATO members in Western Europe, including advanced systems, poured into Greece and Turkey.viii In addition Sofia complained that Yugoslavia never signed the Treaty and thus was under no international obligation to limit its military power or participate in a confidence-building framework.

Consecutive Bulgarian governments adopted different policies to address the perceived threat. The short-lived first non-communist government of Filip Dimitrov in 1991-92 reoriented Bulgarian foreign policy toward greater cooperation with the West and Turkey. In this period, however, the Bulgarian leadership, with a few exceptions, did not actively seek NATO membership as a means of guaranteeing national security.ix Dimitrov's policy led to improved ties with Ankara, which was pleased to see changing treatment of the country's Turkish minority.x The two countries signed a Treaty of Friendship, Goodneighborliness, Cooperation and Security in May 6, 1992. Along with economic and social agreements, the two governments arranged to develop 
Tashev, Blagovest. A la búsqueda de la seguridad: la política de seguridad búlgara en transición.

bilateral confidence-building measures. Accordingly, Sofia and Ankara signed in December 1991 the Sofia Document on Mutually Supplementing Measures to Strengthen Confidence and Security and Military Contacts Between Bulgaria and Turkey, in which they agreed to give each other advance notice of military exercises taking place within 60 kilometers of the borders, an exchange of military observers, etc. Military strength along the border was reduced on both sides. The Sofia Document was later strengthened by the Edirne Document on Some Additional Measures for the Strengthening of Security and Confidence and Military Contacts, signed in 1992.xi The Edirne Document reduced the threshold for military activity notices and expanded the cooperation in military training and contacts.

Similar attempts were made to establish security ties with Greece. The Bulgarian-Greek Treaty of Friendship, Good Neighborhood, Cooperation and Security was signed in October 1991 to last for period of 20 years. The two countries also signed in December 1992 a confidence building agreement committing to lowering the Vienna Document's threshold on the number of troops, tanks and artillery pieces involved in military exercises.

Despite Bulgaria's early attempts to address its security concerns by seeking more extensive security ties with the West, in general, and regionally with Turkey and Greece, the Bulgarian leadership continued to see the country as dangerously exposed in an uncertain security environment. Political and military leaders continued to compare the national force structure and armaments with those of Turkey and Greece.xii Discussions of the deteriorating state of the Bulgarian military and the increasing scope of military hostilities in Yugoslavia frequently evoked comparisons to the accelerated modernization of the Greek and especially the Turkish military forces as a result of the cascading transfer of weapons systems from Western Europe. Although Bulgaria dramatically increased its ties with the West, the lack of security guarantees forced the country to fall back on previously tested security ties. In contrast to most other East European countries, Bulgaria did not see Russia as security threat to its independence and territorial integrity. Accordingly, in August 1992, Bulgaria and Russia signed a Treaty on Good Neighborliness and Friendly Relations, which went beyond similar treaties between Russia and its former Warsaw Pact allies, as two of the articles in this treaty were security related. Article 4 states that consultations will be held if a particular situation endangers international peace and security, and Article 5 that "none of the contracting parties shall allow its territory to be used for military aggression or other violent activities against the other contracting party."xiii Some Bulgarian politicians interpreted the treaty as leaving the possibility of Russian military assistance to Bulgaria. Sofia was also highly encouraged by the fact that the treaty was signed during a visit of Russian President Boris Yeltsin to Sofia, his first visit to a East European country as a head of state. Yeltsin also promised his guests more oil deliveries and greater access to the Russian market.

The signing of the treaty coincided with an increased sense of insecurity among the public. While in 1991 and 1992 the world closely followed developments in Yugoslavia, the Bulgarian public seemed preoccupied with the domestic transition process and disinterested in the disintegration of the neighboring state.xiv National media provided little coverage of the conflict and politicians found it only too convenient to avoid taking a stand on events over which the country seemed to have no control, influence, or interest. 
Tashev, Blagovest. A la búsqueda de la seguridad: la política de seguridad búlgara en transición.

In early 1993 , however, Bulgaria was forced to take a more definite stand on the conflict in Yugoslavia, as the West demanded that the Bulgarian government meet its obligations under international law and enforce the embargo on the neighboring country. Yugoslavia was regularly defying international sanctions and using the Danube River to smuggle in badly needed supplies. Pressed to meet its obligations and fearful of provoking conflict with its neighbor, the government of Berov requested from the EU and the U.S. security guarantees and assistance but received none. In February 1993, Bulgaria ruled out the unilateral use of force to halt the convoys along Danube.

Only in 1993 did part of the Bulgarian political leadership, notably the Union of Democratic Forces (UDF), begin to seek NATO membership as a guarantee for national security. After the Bulgarian Socialist Party (BSP) formed a majority government headed by Zhan Videnov in 1994, however, the issue of joining the Alliance became extremely politicized as the Socialists concluded that NATO was not the answer to national security concerns. Although the new government maintained formal relations with the Alliance, it was clear that the formal membership was not a foreign policy priority.xv The Socialist government proved to be much more conservative in it foreign policy as its displayed a tendency to fall back on historically tested alliances and affinities. During the Cold War Bulgaria and Greece developed relatively close ties, an affiliation based on the shared mistrust of Ankara. Following the UDF government's policy that led to strained relations with Russia and especially with Greece, after Bulgaria recognized Macedonia the Socialist government embarked on restoring ties with Moscow and fostering an even closer relationship with Athens. Thus Bulgaria tried to address its security needs by establishing closer relations with what it saw as historically tested allies while gradually isolating itself from the broader process of the East European countries' forging of increasingly extensive relations with the West. In fact, Bulgaria's shunning of NATO membership was accompanied by difficult relations with other institutions including the EU, the International Monetary Fund, and the World Bank.

Better relations with Moscow and Athens did not, however, translate into perceptions of more security on the part of the ruling elite. Politicians and military elites continued to compare the structure and power of the national military forces with those of neighboring countries.xvi Even Yugoslav troops, although deployed to fight Muslim and Croat forces, were seen as one of the best-equipped armies in Eastern Europe and thus superior to the deteriorating Bulgarian military. At the same time, NATO was perceived to have encouraged an arms race on the Balkans to Bulgaria's disadvantage by further cascading weapons from Central Europe to Greece and Turkey.xvii This perception was shared not only by the Socialists but also by some in the opposition UDF.xviii

The Socialist government defined national security in narrow, traditional terms reflecting the government's preoccupation with external threats and risks. In the National Security Concept approved by the Videnov government on 13 July 1995, national security is defined as the lack of immediate threat of military aggression, political control, or economic coercion to the state and the society.xix

The Concept identifies international and domestic factors determining the state of national security. While the document recognizes the growing multiplicity of international threats and risks, it firmly identifies the traditional, specifically regional, hard-core threats-regional civil wars and their spill-over potential, 
Tashev, Blagovest. A la búsqueda de la seguridad: la política de seguridad búlgara en transición.

historical conflicts among some Balkan states, serious asymmetry of institutional security guarantees among states, demands for territorial changes, and the emergence of new states after Yugoslavia's disintegration-as the most significant security challenges to national security. The document warns that the growing asymmetry between the military power of Bulgaria and most of its members may lead in the future to aggression against the country. Very significantly, the Concept fails to state that Bulgaria does not see an immediate threat to its territorial integrity and sovereignty stemming from the conditions existing in the region.

Although the Videnov government did not identify any country as threatening national security, it implicitly regarded Bulgaria's traditional enemies, especially Turkey and Yugoslavia, as posing a threat to national sovereignty. Although no country in the Balkans had declared any territorial claims to Bulgaria, the government and part of the society seemed to assume them.xx Both failed to realize that Yugoslavia had no intentions of antagonizing Bulgaria and, in any event, Belgrade was in no position to mount any effective military challenges to the East. In addition, Sofia's preoccupation with the growing military disparity between Bulgaria, on the one hand, and Greece and Turkey on the other, indicated a misreading of the security dynamics between Athens and Ankara. In fact, the two countries came to blows in the midd-1990s over their deep divisions involving Cyprus, air space, territorial waters and treatment of minorities, and both were only happy to maintain unproblematic relations with Bulgaria.

The document also contains an implicit criticism of the previous governments' policies, which led to severe economic and social problems, in turn severely exposing the country to threats and risks. It points out that the country neglected traditional allies in its pursuit of integration in international institutions without regard for national autonomy and interests. According to the Concept, the state's goal is to guarantee its territorial integrity and sovereignty, to ensure the conditions for economic development and to guarantee the democratic character of the society, among others. The decisive way of achieving this is through the sustained process of increasing national power, active cooperation and coordination with international partners and stimulating the nation's patriotism and loyalty to the state through sustained economic and social prosperity. National interests can be protected by relying mainly on the national military forces. Moreover, military security is seen as determined by the strategic, political and military factors in the international environment, on the one hand, and national military capacities, on the other. Although the concept defines cooperation with international institutions and friendly states as an additional way to guarantee security, it makes no explicit commitment to seeking integration in NATO as a major foreign policy goal. Instead, it suggests that Bulgaria may seek NATO membership only after the Alliance transformed itself into one of the elements of a pan-European security framework in which Russia will have a major role. Accordingly, while membership in the EU and the WEU is defined as a priority, the relationship with NATO is seen as a partnership.

The Videnov government's Concept reflected the emergence of a deep division among the political elite over the nature of national security and how best to achieve it. While the Socialists' conception perceived the issue in largely traditional ways, emphasizing the accumulation of mostly military power and the 
Tashev, Blagovest. A la búsqueda de la seguridad: la política de seguridad búlgara en transición.

maintenance of alliance with friendly states, the UDF opposition insisted that integration in both the EU and NATO is both consistent with Bulgaria's quest to join a community of states sharing common values and the best way to guarantee the country's security and prosperity.xxi The BSP government correctly concluded that membership in both organizations is only a distant possibility and was skeptical of the organizations' ability and willingness to address the country's security needs.xxii Yet Bulgaria, in their view, was facing immediate and grave threats and challenges.xxiii The government saw neighboring states as competitors, some of which--Greece and Turkey--were already members of a security organization which Bulgaria had no chance of joining in the neat future. Consequently, Bulgaria fell back on already tested security arrangements by reviving its close relations with Russia and cultivating more extensive cooperation with Greece.xxiv

In addition to its reverse in foreign and security policies, the government also ended the gradual reduction in military budgets implemented by previous governments. At the wake of communism's collapse, Bulgaria was spending $\$ 2.46$ billion on its military, accounting for more than 4.5 percent of the GDP.xxV After declining to 2.5 percent of the GDP in 1994, the Videnov government refused to implement further military reforms and maintained the armed forces' structure and high budgets. In fact while in Eastern Europe military budgets were declining, Bulgaria continued to have high military expenditures, becoming a heavy burden on the stagnated economy.xxvi

The public seemed to share some of the government's assumptions about security. The relatively strong relationship with Russia established by the bilateral treaty in 1992 and enhanced by the Videnov government after 1994 was an unproblematic issue in domestic politics. In 1992 only 6 percent of the public perceived Russia to represent a threat to Bulgaria and by 1994 only 5 percent seemed to share this perception.xxvii In fact, the Bulgarian public did not see any of the great powers as posing any threat to its security. In 1992 and 1996, only 3 percent perceived Germany to be a threat, and 4 and 9 percent respectively saw the US as a threat.xxviii In other words, neither a single great power nor a conflict among great powers was seen to be a likely threat to national security. Conversely, in 1992, 61 percent of the public perceived neighboring countries as representing a threat to peace and security in Bulgaria, although by 1996 this feeling of threat was shared by only 31 percent.xxix Threats emanating from the region and within countries were perceived to be the most likely challenges to national security. The beginning of the Yugoslav conflict generated a sense of grave insecurity; the negotiated end of the war in Bosnia and the consequent deployment of NATO peacekeeping forces in late 1995 only slightly abated the public's security apprehensions. Raging and dormant ethnic conflicts in the region heightened security fears about the possible threat posed by Bulgaria's own ethnic groups. Remarkably, in the decade following the collapse of communism the public never ceased to see ethnic minorities as a possible threat to territorial integrity and national security. 
Tashev, Blagovest. A la búsqueda de la seguridad: la política de seguridad búlgara en transición.

\section{EARLY RELATIONS WITH NATO}

The beginning of Bulgaria-NATO relations was laid down by a decision of the Bulgarian government in 13 July 1990 to accept the invitation extended by the London Declaration of the NACC to establish diplomatic links with the Alliance. Compared to the other East European countries, however, Bulgaria remained ambivalent toward membership in NATO as there was no domestic consensus on the foreign policy priorities of the country. The Socialist Party, internally split on foreign policy priorities, either insisted that the Alliance should first transform and even agree to accept Russia as a member before Bulgaria's accession to the Alliance or outright resisted any moves to establish long-term relations with NATO.xxx On the other hand, the pro-Western UDF remained internally divided and ineffective in making the case for membership. In fact, the only consistent and forceful voice of support to the idea of joining the Alliance was the first democratically elected president, Zhelju Zhelev.

Bulgaria's ambivalence on relations with NATO between 1990 and early 1997 left the country unprepared for integration in the Alliance. The Parliament passed a declaration in December 1993 on the Euro-Atlantic orientation of the country and on 14 February 1994 the country signed the Partnership for Peace Framework Document.xxxi The Socialist Party, however, undermined any attempt to establish solid relationship with the Alliance and after its overwhelming electoral victory in 1994 put the relations on hold. In 1996, after rounds of discussions with NATO in accordance with the PfP guidelines concerning prospective desire to join the Alliance, Bulgaria concluded that it did not want to pursue membership.xxxii

\subsection{Change of course after 1997}

The ascendance of UDF to power in early 1997 dramatically changed Bulgaria's approach to cooperation with and integration in the international community. Bulgaria saw membership in NATO, the EU and the WEU not only as a reliable source of security guarantees but also as a natural expression of the country's foreign policy orientations. Accordingly, the Kostov government not only reoriented the country's foreign policy but also altered its approach to security.

The National Assembly approved in April 1998 a new National Security Concept which reflected the new government's security policies and priorities.xxxiii Like the Concept of the previous government, the new one identifies both external and internal factors affecting and determining national security. Although the document sees a considerably decreased danger of direct military aggression against Bulgaria, it still emphasizes the importance of military and force factors in international relations. In contrast to the previous government's approach, however, the new Concept recognizes the inability of the country to ensure its security on its own or to seek security through neutrality, because of insufficient financial, economic and military potential. Instead it identifies integration in international organizations and participation in the globalization process as the means to address these shortcomings. Along with identifying the national scarcity of security resources, the document points out that national security is affected by world economic, political, scientific and environmental processes as well as regional developments. Thus it becomes very unlikely that unilateral decisions, including military ones, are imposed in regional and bilateral conflicts. The Concept points out that these developments--scarcity of national resources, 
Tashev, Blagovest. A la búsqueda de la seguridad: la política de seguridad búlgara en transición.

the significance of world processes, and the institutional, rather than unilateral, solution of problems--prompts Bulgaria to seek security through transition to democracy and a market economy and integration in Euro-Atlantic institutions, including the EU and NATO. Significantly, the lack of security and stability until recently were caused by the failure of the previous government to pursue these same policies. In other words, it is not mainly the external threats that affected the state of national security but the failure to advance reforms and the refusal to integrate in the Euro-Atlantic institutions.

The new Concept, like the old one, devotes much attention to threats in the Balkans, especially the ones associated with the conflicts in Yugoslavia. The effects of the crisis in the neighboring country are seen not in the form of a direct military challenge but rather as the existence of conditions for the development of organized crime and corruption and for the isolation of Bulgaria from the process of integration in the Western institutions. These conditions jeopardize the stability of the Bulgarian state institutions whose integrity is a precondition for national security. In other words, the regional threats to national security are not in the form of direct military challenges to the territorial integrity and sovereignty of Bulgaria but in their effects on the capacity of the country to reform and integrate in Western institutions. Bulgaria's perception of regional and limited threats to its national security were also evident in its Military Doctrine, which did not envision any direct military threat but defined any armed conflict in the Balkans as potentially presenting the challenges already identified in the Security Concept.xxxiv Significantly, after the UDF's ascendance to power, political leaders and officials ended their references to any military unbalances between Bulgaria and its neighbors as Greece and Turkey were already seen as soon-to-be allies. Even the Socialists, although fundamentally opposed at least until 2000 to a membership in NATO, were unable to generate public support for their security and foreign policies. In fact, while in opposition after disastrous electoral results in 1997, the BSP did not develop any cohesive foreign policy vision of its own.

The new security concept was adopted shortly before a new escalation of armed conflicts in the Balkans. In early 1999 NATO initiated air strikes against Yugoslavia, the second such action in less than four years. This time the military action was even closer to Bulgarian territory, in Kosovo and Serbia, and presented an even more dramatic challenge to national perceptions of security. Both the rhetorical and already institutional commitment to Euro-Atlantic integration, forced Bulgaria to take a firm stand on the conflict. In contrast to the 1991-96 period, when Bulgarian governments saw neutrality and noninterference as the best guarantee of national security, the Kostov government committed the country to the Alliance's strikes, including providing overflight rights, imposing sanctions on Serbia in accordance with EU associate members' obligations, and urging Belgrade to accept the international community's conditions.XXXV

It must be noted, however, that the government's decision to support the West in the conflict was taken over the public's disapproval of NATO's action and of the government's involvement in the conflict.xxxvi UDF was the only party, which unequivocally supported the NATO air campaign, while the BSP strongly objected and frequently criticized the agreement between the Alliance and the government. Public resistance reflected the perception of an acute threat to 
Tashev, Blagovest. A la búsqueda de la seguridad: la política de seguridad búlgara en transición.

national security and exposed the public's belief that neutrality to conflicts in the Balkans is still the best guarantee for Bulgaria's security.xxxvii

Although the perception of insecurity was widespread, the public did not exactly identify the nature of the threat posed by the Kosovo conflict. Yugoslavia did not issue any specific warnings about Bulgaria's support to NATO's action as Sofia's behavior did not substantially differ from the policies of the other Balkan countries, which provided political and practical assistance to the Alliance. Moreover, Bulgaria did not turn into a destination for refugees leaving Kosovo, and aside from several stray American missiles landing on Bulgarian territoryxxxviii the short war did not inflict any damages on the country.xxxix Yet the public was afraid the country would be dragged into the conflict.xl Despite government assurances that Bulgaria was ready to face any challenge with the assistance of Western Europe, and despite the widely publicized NATO commitments to national security, the public remained skeptical.xli Conversely, the ruling elite saw the crisis as enhancing Bulgaria's security as it prompted Euro-Atlantic institutions to further assist Bulgaria's quest to join the West.xlii In fact, the successful conclusion of the Alliance's air campaign against Serbia marked the transformation of the BSP's position on the country's membership in NATO. After a relatively short and uncontroversial intra-party debate, the Socialists decided to embrace NATO membership as the only politically attainable means to guarantee national security.xliii The change in the BSP's long-standing opposition to NATO was an attempt by the party leadership to transform the party into a modern social-democratic organization and position itself as a potential coalition partner ahead of the 2001 parliamentary elections.xliv Even then, however, the Socialists remained the only party represented in the Parliament, which insisted that the country should hold a referendum on NATO membership.

\subsection{Relations with NATO: a new beginning}

The collapse of the Socialist government in early 1997 marked not only the ascendance of the UDF but also a dramatic change in the country's foreign policy priorities. One of the first acts of the interim government of Stefan Sofiyanski was to declare Bulgaria's aspiration to join the Alliance.xlv After the UDF won the parliamentary elections and formed a stable majority government, the country became quite active in its quest to establish a strong relationship with the Alliance and ultimately gain membership. The government quickly established an infrastructure to catch up with the other candidates. On 17 March 1997 Bulgaria adopted the National Program for Preparation and Accession to NATO and set up an Intergovernmental Committee on NATO Integration. Yet, it was obvious that the country had lost valuable time and the final document of the Madrid Summit, which did not even mention Bulgaria as a potential future member, caused disappointment in the country but came as a no surprise.

Indeed, political will aside, Bulgaria was hardly prepared to join NATO. While the country met some of the criteria listed in the NATO Enlargement Study, including democratization, protection of individual liberties, among others, and governmental control over the military, Bulgaria failed to take any substantial steps to reform the military. Until 1997 consecutive governments had not started the restructuring of the armed forces. Since the country did not seriously consider joining NATO no efforts were made to achieve interoperability and 
Tashev, Blagovest. A la búsqueda de la seguridad: la política de seguridad búlgara en transición.

train personnel for work with NATO members. No efforts were made to coordinate its defense budget, planning, and resource management.

The government of the UDF made considerable effort after 1997 to implement wide ranging military reforms, and more importantly, end Bulgaria's selfimposed isolation and convince the Alliance of the benefit of the country's membership. Bulgaria approved its National Security Concept in April 1998, a Military Doctrine in April 1999, a Defense Plan in October 1999, and Partnership Goals in April 2000.xlvi The government also established an inter-departmental structure, co-chaired by the foreign and defense ministers and an integration council in the Ministry of Defense, to coordinate NATO integration.

At the time of the UDF's ascendance to power in early 1997 the size of the military was still at pre-1989 force levels and structure. The new defense reform envisioned in the so-called Plan-2004 set out to cut the size of the armed forces from roughly 100,000 to 45,000 by 2004 . It also called for restructuring of the forces in three corps and their gradual modernization to meet NATO standards.xlvii

The crisis in Kosovo in 1999 provided the biggest boost to Bulgaria's attempts to join the Alliance. Even before the beginning of the air campaign, the government intensified its consultations with NATO officials in anticipation of armed conflict.xlviii President Stojanov and Prime Minister Kostov also met with their Balkan counterparts and issued appeals to Serbia's leader Milosevic to accept NATO's plan for solving the crisis in Kosovo.xlix Later, during the air campaign, the government and the Parliament granted the Alliance the use of Bulgaria's airspace for attacks against targets in Yugoslavia. The government recognized that the Kosovo crisis, although posing numerous security challenges to the country, presented a unique opportunity to prove the irreversibility of Bulgaria's transformation, its choice to integrate in the EuroAtlantic area, and more immediately, the strategic value of an aspiring NATO member.I Indeed, Bulgaria's support and cooperation with the Alliance significantly enhanced the country's standing, allowing it to catch up with the rest of the partners in their quest to gain membership. In return for its wartime support, the NAC at the Washington summit in April 1999 extended a limited, in space and time, Article 5 guarantee to Bulgaria.li Even before this explicit statement of commitment, the Alliance on numerous occasions conveyed its interest in the security and stability of the country.lii This was not lost on the Bulgarians and the government widely publicized any statement of support and commitment.liii

The end of allied air strikes in Yugoslavia did not diminish the growing cooperation between NATO and Bulgaria. The need to maintain multinational forces in Kosovo and the beginning of a new conflict, this time in neighboring Macedonia, gave Bulgaria another chance to enhance its status among the aspiring membership candidates. In March 2001 the government agreed to sign an agreement allowing NATO forces to use Bulgarian territory, including the establishment of military bases, in the event of a Balkan crisis.liv Remarkably, all political parties represented in the Parliament supported the agreement and it was approved without the usual resistance from the Socialist Party.Iv 
Tashev, Blagovest. A la búsqueda de la seguridad: la política de seguridad búlgara en transición.

\section{THE GOVERNMENT OF SIMEON SAXE-COBURG GOTHA: STAYING THE COURSE}

The loss of the UDF in the parliamentary elections in 2001 and the ascend to power of the National Movement Simeon II (NDSV) led by Simeon Saxe-Coburg Gotha did not change significantly Bulgaria's foreign policy priorities. NATO membership remained the foundation of the country's security policy. What changed, however, was the international security environment. The terrorist acts in the United States on 11 September 2001 and America's changing military posture considerably enhanced Bulgaria's changes of actually joining the Alliance. It also posed new challenges to the country's ability to operate in a complex security environment.

The new government, including NDSV and the Movement for Rights and Freedoms (MRF), continued the reforms in the armed forces in accordance with Plan 2004 and the Membership Action Plan (MAP), and at the same time actively sought diplomatic support for its membership aspirations. In late 2001 and early 2002 it became apparent that the NATO allies, and mainly the United States, were willing to welcome more states to the Alliance. On 22 November 2002 in Prague Summit took a decision to invite Bulgaria along with six more states.

In contrast to the first three post-Cold War members, the future members of the new wave of NATO expansion seem better prepared to integrate into the Alliance and take on full responsibilities. Bulgaria's membership preparation takes place within the framework of three relevant basic processesMembership Action Plan (MAP), Partnership for Peace (PfP) and the Planning and Review Process (PARP). The country is currently in the fourth cycle of the Annual National Program (ANP) under the MAP and it is expected to implement a fifth one as well. This process allows the invited countries to smoothly move from annual PARP to defense planning in the framework of NATO. Thus Partnership Goals will be substituted by temporary Target Force Goals or directly by NATO Force Goals. One of the big disappointments after the first wave of expansion was the inability of the three countries to meet their ambitious commitments under the Force Goals. This time MAP created the conditions for a more realistic assessment of each country's own capacities to meet newly formulated commitments. In other words, Bulgaria already has experience in the institutionalized process of negotiating forced commitments and should have no problems participating in the NATO Force Goals process.

However, Bulgaria's impeding membership in NATO and the European Union have brought not only better perepectives for the future, but new challenges as well. The transatlantic tensions that became especially acrimonious during the recent Iraq crisis revealed Bulgaria's precarious position and made it clear that in the near future policy-makers will have to balance their actions to achieve two goals-attaining a membership in the EU and an effective membership in NATO.

During the Iraqi crisis Bulgaria, while fully devoted to its priority of joining the $E U$, reluctantly maintained a strong pro-American stand in the trans-Atlantic spat. Being a non-permanent member of the UN Security Council, Bulgaria had no choice but to take public stands, which obviously contradicted the positions of France and Germany, two countries whose political support Bulgaria needs in the process of joining the EU. The relations between Bulgaria and France 
Tashev, Blagovest. A la búsqueda de la seguridad: la política de seguridad búlgara en transición.

reached the lowest point in February 2003, when the country was warned by the French President Jacques Chirac that its pro-American position might endanger the prospects of attaining EU membership. Indeed, although all East European states were warned, Bulgarian and Romania received a special attention in Chirac's public outburst.

The end of the Iraqi war and the improving relations between the U.S. and the European states opposing the war do not, however, eliminate future threats to Bulgaria's balancing act between the competing visions on both sides of the Atlantic. The recently formulated vision of creating an independent European defense identity proposed by France, Germany, Belgium and Luxemburg is yet another reason for Bulgarian decision-makers to worry about further tensions in the Euro-Atlantic community which would inevitably place the country in an uncomfortable position to once again make choices it wants to avoid. For now, however, the country continues its policy of providing support to the American war on terrorism while seeking a quick completion to accession negotiations with the EU. For instance, a 800-strong Bulgarian contingent participates in Iraq and political leadership recently expressed political will to host American military bases.Ivi

However, the Iraqi crisis also revealed the fragility of the political consensus on Bulgaria's security policies. While the ruling majority and the UDF supported the country's pro-American position, the BSP and most of the society opposed the war. Thus, it appears that while there is consensus on the country's EuroAtlantic integration, political parties have quite different visions of Bulgaria's precise place and role in the community.Ivii

\section{CONCLUSION}

Geostrategy defines Bulgaria as a state on the periphery of the Euro-Atlantic space, facing risks and threats emanating from the Balkans, the Middle East, the Caucasus, and the former Soviet Union. Threats and risks from these regions will influence strategic thinking in Bulgaria for many years to come. In fact, these security challenges are not specific to Bulgaria but to the entire EuroAtlantic area. In other words, Bulgaria's integration in NATO and the EU will not diminish threats to national security but simply increase the country's capacity to face them. Inevitably, being in the periphery is bound to dominate strategic thinking; in the near term, decision-makers are always tempted to formulate security policies for traditional threats and risks, thus ignoring developments and trends beyond the immediate security environment.

At the same time, Bulgaria faces risks and threats common to the Euro-Atlantic area including terrorism, organized crime, weapons of mass destruction, and mass migration. Indeed, in the last year three Bulgarian citizens became victims of terrorist acts on three separate occasions and none of them took place in the country. Integration in the Euro-Atlantic area de-nationalizes Bulgaria's security policy as national security becomes a part of the community security. Thus, security policy must be formulated in close cooperation with allies and synchronized with the Euro-Atlantic community's security needs. In the short term, the great challenge facing the political elite and military planners is to recognize that Bulgaria's integration in the Euro-Atlantic space to a great extent denationalizes the national security policy and accordingly change the national policy including in defense planning. And logically, Bulgaria would be on 
Tashev, Blagovest. A la búsqueda de la seguridad: la política de seguridad búlgara en transición.

receiving end of any further tensions between the big states in the Euro-Atlantic space.

In addition to external threats and risks, Bulgaria faces numerous domestic challenges typical for all transition countries in Southeast Europe. Weak institutions, political instability, the slow pace of reforms, uneven economic development, social stratification, and organized crime and corruption are only some of the threats and risks challenging the ability of the states to provide basic security to its citizens. These threats were identified and widely discussed in the literature on democratization early in the post-communist period. However, while the countries of Central Europe proved capable of dealing adequately with most challenges and thus disproving the early pessimistic scenarios of the future of East Europe, Bulgaria facing more numerous threats and risks, has yet to demonstrate ability to deal with them effectively. In other words, Bulgaria's security policy faces the double-edged challenge of having to attain security in a threat-rich environment while possessing limited capabilities. Bulgaria's place in the world is determined by its interests as a nation and its future full membership in the Euro-Atlantic community. For very long in the postcommunist period, the political elite did not achieve a consensus on the national interests and the ways to attain them. Compared to the other East European countries Bulgaria remained ambivalent toward membership in NATO as there was no domestic consensus on the foreign policy priorities of the country. Although it might be argued that the society and political elite have finally achieved a consensus on the place of the country in the world, it is still too early to discern any fledging consensus on Bulgaria's security needs, especially on the ways to achieve security. In other words, the political elite and the society are yet to define what the country's role in the Alliance ought to be.

There is a real danger that once Bulgaria becomes a NATO member, the political elite may conclude that the membership itself guarantees national security. If such a perception is to dominate strategic thinking, Bulgaria's security policy may lead to predominate investments in traditional, regionallyoriented security and defense capabilities while expecting the Alliance to add further resources to the national security capacity. In such thinking almost all of the future security risks and threats are of the traditional type, including conflicts between states. Such policy would turn Bulgaria into a consumer of security, which adds little to the security capacity of the Alliance. Indeed, despite almost four years of defense reform, the armed forces are yet to change radically their structure, missions and capabilities.

If no change in strategic thinking is to take place, Bulgaria will then assume a relatively low-profile in the Alliance doing only the minimum required as a member and frequently refusing to take a firm stand on issues which do not appear to concern the narrowly defined national interest. Ultimately however, such strategic thinking and policy would not substantially enhance national security. In a security environment wherein most threats and risks would not very likely require allied actions falling under Article 5 of the Washington Treaty, the reliance on security policies translates into little added security. Therefore, it is extremely important for the sake of the future enhanced national security that the political elite and the society achieve a consensus on the thinking that more security in the Alliance is achieved through active participation in its future expanded policies and missions. 

transición.

i“Pact Outlived Its Time." CTK in English (1 February 1991).

"Foreign Minister Boyko Dimitrov rejected the idea that Bulgaria might join NATO and instead called for the simultaneous dissolution of both alliances. Ricardo Estarriol, "Foreign Minister Views European Issues" (text). Barcelona La Vanguardia

Spanish (date not given). Translated by the Foreign Broadcast Information Service. FBIS Daily Report-East Europe, 29 March 1990 (PrEx 7.10: FBIS-EEU-90-061; p. 8-9).

iii'Defense Minister Yordan Mutavchiev suggested that after the dissolution of the Warsaw Pact, Bulgaria must rely on its own defense forces and bilateral treaties with the Soviet Union. Zvyatko Belenski and Ivan Staevski, "Our Military Doctrine is Defensive." Sofia Otechestven Vestnik in Bulgarian (21 November 1990); Pesident Zhelev's spokesman, Valentin Stoyanov, argued that Bulgaria will seek security through improved relations with Balkan neighbors, positive relations with East European countries, including the Soviet Union, but mainly through internal stability. "New Military, Security Doctrine Discussed." Bulgarian Telegraph Agency in Bulgarian (3 February 1991).

iv See interview with Minister of Foreign Affairs Viktor Vulkov. Vikhra Rizova, "Bulgaria Has Renounced the Satellite Syndrome." Anteni in Bullgarian (26 June 1991).

vJoseph Rothschild, Return to Diversity: A Political History of East Central Europe Since World War II (New York: Oxford University Press, 1993); Barbara Jelavich, History of the Balkans (New York: Cambridge University Press, 1983).

${ }^{v i}$ On the Bulgarian perspective on military implications of the Yugoslav conflict see Michail Srebrev, "Southern Europe: Concerns and Implications from a Bulgarian Perspective," in Charles L. Barry, ed., The Search for Peace in Europe: Perspectives from NATO and Eastern Europe (Fort Lesley: National Defense University Press, 1993).

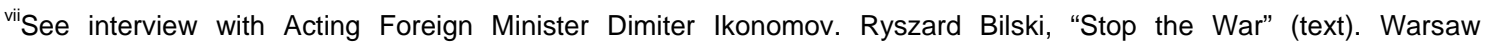
Rzeczpolita in Polish (25 February 1993). Translated by the Foreign Broadcast Information Service. FBIS Daily ReportEast Europe, 4 March 1993 (PrEx 7.10: FBIS-EEU-93-041; p. 4-5).

viii See statement by President Zhelev in the daily Balgarska Armia in Bulgarian (18 November, 1991), 1.

${ }^{i x}$ In his election address before the 1991 parliamentary elections, UDF leader and future Prime Minister Filip Dimirtov listed Bulgaria's integration in the EC as a number one foreign policy priority, but failed to even mention NATO. "Election Address." Demokratsiya in Bulgarian (16 September 1991).

×Duncan M. Perry, "New Directions for Bulgarian-Turkish Relations," RFE/RL Research Report 1, no. 41 (16 October, 1992): 33-40.

xi، Military Accord with Turkey," RFE/RL Research Report 1, no. 48 (4 December, 1992), 58.

${ }^{x i i}$ Statements by President Zhelev and General Tsvetan Totomirov. Bulgarian Telegraph Agency (2 October, 1994).

xiii'Kyril Haramiev-Drezov, "Bulgarian-Russian Relations on a New Footing," RFE/RL Research Report 2, no. 15 (9 April, 1993): 33-38.

${ }^{x i v} K j e l l$ Engelbrekt, "A Vulnerable Bulgaria Fears Wider War," RFE/RL Research Report 3, no. 16 (22 April, 1994): 7-12.

${ }^{x v}$ Lecture of the Prime Minister of Republic of Bulgaria, Zhan Videnov before the Atlantic Club in Bulgaria, 4 April 1995. Available from the Atlantic Club in Bulgaria.

xvi Vasil Lyutskanov, "Army Needs Urgent Modernization, Or We Will Be Hopelessly Behind in One or Two Years," Sofia Trud in Bulgarian (6 February 1995).

xvii Liubomir Denov "At One Stroke, NATO Pushes Us Into a New Arms Race." Sofia 24 Chasa in Bulgarian (27 Ocotober 1994), 10.

xviii Nikolay Slatinski, former Chairman of the National Assembly's National Security Committee, worried in early 1995 that the Conventional Forces in Europe Treaty exacerbated an already great regional imbalance to Bulgaria's detriment by allowing modernization of weapons system and cascading of military hardware to Greece and Turkey. Given the economic and social crisis in the country, Bulgaria was seen as unable to compete and keep up with these countries. See Nikolay Slatinski and Marina Kaparini, "Bulgarian Security and Prospects for Reform." NATO Review no. 2 (March 1995): 28-32.

${ }^{x i x}$ Council of Ministers of the Republic of Bulgaria, National Security Concept of the Republic of Bulgaria. In Bulgarian (Sofia, 1995).

${ }^{x x}$ In an interview with the Kontinent daily, Turkey's president Suleyman Demirel was asked to assure the Bulgarian public that his country had no evil designs on Bulgaria or the Balkans. "Suleyman Demirel, Interview." Sofia Bulgarian Telegraph Agency in English (10 December 1993).

${ }^{x x i}$ On the UDF's view of Bulgarian membership in NATO in 1994 see interview with then Deputy Defense Minster and a future Defense Minster in the Kostov government, Boyko Noev. Lyubomir Denov, "Boyko Noev: The Time for Neutrality Has Passed." Sofia 24 Chasa in Bulgarian (11 March 1994).

xxii The Socialists' mouthpiece Duma commented that the signing in 1994 of a memorandum by the Bulgarian government and visiting U.S. Defense Secretary William Perry was serving America's strategic interests in the Balkans, but none of Bulgaria's. "Bobi Michailov is Not Guarding the State's Goal." Sofia Duma in Bulgarian (20 July 1994).

xxiii The public seemed to share the Socialists' perception of the likelihood of NATO accession. In 1995 only 31 percent of the public believed that accession within five years was likely. United States Information Agency, The New European Security (Washington, DC: Office of Research and Media Reaction, September 1995), 15; The public also seemed to have little confidence in international organizations. 35 percent trusted OSCE, 29 percent trusted WEU, and 33 percent expressed trust in NATO. Ibid., 33. 

transición.

${ }^{\text {xxiv }}$ Russia was more than happy to reward Bulgaria's lack of interest in NATO. In July 1995 Moscow sent to Bulgaria free of charge 100 T-72 tanks along with armored fighting vehicles. Kontinent (27 February, 1995), 7.

${ }^{x x v}$ International Institute for Strategic Studies, The Military Balance (London: Oxford University Press, 1990), 84.

xxvi It must be noted that differences in accounting practices explain the discrepancies between figures provided by Bulgaria's Ministry of Defense and Western sources such as The Military Balance. Thus according to the Ministry of Defense between 1990 and 1996 the budget for defense averaged slightly over 3 percent of the GDP and in 1997 and 1998 it declined to slightly over 2 percent. In any event, until 1996 the military budget remained high by East European standards. For budgetary estimates see Ministry of Defense of the Republic of Bulgaria, Parliamentary Oversight and Democratic Control of the Bulgarian Armed Forces and Ministry of Defense, study no. 3/1998 (June 1999). Available from http://www.md.government.bg; INTERNET.

${ }^{x x v i i}$ At the same time in most other East European states the perception of threat from Russia actually increased. Christian Haerpfer, Claire Wallace and Richard Rose, Public Perceptions of Threats to Security in Post-Communist Europe (Glasgow, Scotland: University of Strathclyde, Center for the Study of Public Policy, 1997), 6.

xxviii Ibid., 6-11.

${ }^{\text {xxix }}$ Ibid., 12.

${ }^{x \times x}$ See Videnov, 3-5; Council of Ministers of the Republic of Bulgaria, National Security Concept, 34.

${ }^{x \times x i}$ Nikolay Slatinski and Marina Kaparini, "Bulgarian Security and Prospects for Reform," NATO Review no 2 (March 1995): 28-32.

xxxii Jeffrey Simon, "Bulgaria and NATO: 7 Lost Years," Strategic Forum no. 142 (May 1998). Available from http://www.ndu.edu.

xxxiii Government of the Republic of Bulgaria, National Security Concept (June 1999). Available from http://www.md.government.bg.

xxxiv The military doctrine was approved on 8 April, 1999. Government of the Republic of Bulgaria, Military Doctrine of the Republic of Bulgaria. (June 1999). Available from http://www.md.government.bg; INTERNET.

${ }^{x \times x v}$ In a sharp reversal of previous Bulgarian policy of neutrality toward Yugoslavia, President Stoyanov stated that Bulgaria's long-erm interests did not coincide with the interests of today's leadership of Yugoslavia and described the conflict as "a collision between the democratic community and the last communist regime in Europe." "Bulgaria Sides with NATO Over Kosovo," Agence France-Presse (16 April, 1999); In an interview for Le Mond, President Stoyanov noted that in the past seven years Bulgaria had been a hostage of Milosevic's policies and that it is time to solve the Serbia problem. Bulgarian Telegraph Agency (5 May, 2001); In an interview for the daily Trud, Prime Minster Ivan Kostov stated that Bulgaria cannot have a neutral policy toward the Kosovo crisis for neutrality would bring about more threats to Bulgaria. Valeriya Veleva, "You Stop Violence with Violence." Sofia Trud in Bulgarian (3 May 1999).

xxxvi In March 1999, 72 percent of the public was against NATO military intervention in Yugoslavia and 77 percent were against NATO equipment and personnel crossing Bulgaria. "Bulgaria--Survey--Kosovo," Bulgarian Telegraph Agency (23 March, 1999).

xxxvii In the same survey, 58 percent of the public viewed the conflict in Kosovo as the worst threat to national security. While one-third considered NATO guarantees a reliable protection only 59 percent said Bulgaria would be better protected if it did not allow its territory to be used in a possible attack on Yugoslavia. Ibid.

xxxviiiu“Fifth Stray NATO Missile Hits Bulgaria," Agence France-Presse (7 May, 1999).

${ }^{x x x i x}$ During the air campaign the Bulgarian military was not placed on higher alert although some special security measures were implemented, including additional security for the nuclear plant in Kozloduy. Galina Sabeva, "Bulgarian Leaders Work to Grant NATO Request," Reuters (19 April, 1999).

${ }^{x 1}$ Anatoly Verbin, "Bulgarian Government Tested Over Kosovo," Reuters (19 April, 1999).

${ }^{x i}$ Durign the crisis Bulgaria and the Alliance held intensive consultations, and in late 1998, NATO Secretary General Javier Solana sent a letter, which, according to Prime Minster Kostov, provided security guarantees to the country. "Bulgaria--NATO Consultations," Bulgarian Telegraph Agency (13 October, 1998).

xlii The Kosovo crisis was one of the main reasons the EU decided to initiate accession negotiations with Bulgaria. For the political elite's view see President Stoyanov's interview with Le Mond. Bulgarian Telegraph Agency (5 May, 2001).

xiliii"BPS Declares Itself in Favor of Active Partnership with NATO," Bulgarian Telegraph Agency (7 March, 2000); "ExCommunist Socialist Back Bulgaria's NATO Bid," Reuters (6 March, 2000).

xlivu'Socialists Break with Past, Back NATO," Reuters (7 May, 2000).

${ }^{x / v}$ Council of Ministers of the Republic of Bulgaria, 17 February 1997--Decision of the Council of Ministers for Full NATO Membership (November 2000). Available from http://www.md.government.bg.

xlvisee Simon, "NATO's Membership," 10.

${ }^{x}$ vii Ministry of Defense of the Republic of Bulgaria, Military Doctrine of the Republic of Bulgaria. Available from http://www.md.government.bg; INTERNET; Ministry of Defense of the Republic of Bulgaria, Plan 2004 (June 2001). Available from http://www.md.government.bg; INTERNET; Jeffrey Simon, "Transforming the Armed Forces of Central and East Europe," Strategic Forum no. 172 (June 2000). Available from http://www.ndu.edu; Simon, "Bulgaria and NATO."

xlviii، Bulgaria-NATO Consultations," Bulgarian Telegraph Agency (13 October, 1998).

xilix"Bulgaria, Romania Urge Milosevic to Accept NATO Force," Agence France-Presse (22 February, 1999).

Papeles del este.

8(2004): 1-20 
Tashev, Blagovest. A la búsqueda de la seguridad: la política de seguridad búlgara en transición.

'Anatoly Verbin, "Bulgarian Government Tested Over Kosovo," Reuters (19 April, 1999); In a interview, Ivan Krastev, a Bulgarian political scientist, argued that the "crisis in Kosovo makes Bulgaria a real candidate for NATO membership." "Kosovo Crisis Made Bulgaria Visible." Kapital 13 (5 April, 1998).

"In a "Statement on Kosovo," the NAC committed the Alliance to the security and territorial integrity of the countries challenged during the crisis by Serbia's regime. Quoted in Simon, "NATO's Membership," 19.

lii Steve Holland, "NATO Vows to Guard Border States from Serbs," Reuters (25 April, 1999).

liii Interview of foreign minister Nadezhda Michailova. "NATO Extends its Security System Over Bulgaria." Kapital 41 (19 October, 1998); In an interview, Prime Minster Ivan Kostov said that NATO Secretary General Javier Solana had send a letter stating that "NATO is ready to guarantee the security of Bulgaria in a case of attack by Yugoslavia." Bulgarian Telegraph Agency (13 October, 1998).

liv“Deal Will Let NATO Forces to Use Bulgarian Territory," Reuters (29 March, 2001).

IV“Socialists Decide to Vote for Ratification of Agreement with NATO," Bulgarian Telegraph Agency (4 March, 2001).

Ivi Bulgarian Telegraph Agency (16 October, 2003).

Ivii "Parvanov and BSP Against Participation with the U.S. Without UN Mandate." Mediapool.bg in Bulgarian (5 February, 2003); Statement by President Parvanov before the National Assembly. Bulgarian Telegraph Agency in Bulgarian (5 February, 2003). 
Tashev, Blagovest. A la búsqueda de la seguridad: la política de seguridad búlgara en transición.

\title{
BIBLIOGRAPHY
}

\author{
24 Chasa \\ Agence France-Presse \\ Anteni \\ Bulgarian Telegraph Agenc \\ Balgarska Armia \\ CTK \\ Demokratsiya \\ Duma \\ FBIS Daily Report-East Europe \\ Kapital \\ Kontinen \\ Otechestven Vestnik \\ Reuters \\ RFE/RL Research Report \\ Trud
}

Engelbrekt, Kjell, "A Vulnerable Bulgaria Fears Wider War," RFE/RL Research Report 3, no. 16 (22 April, 1994): 7-12.

Haerpfer, Christian, Claire Wallace and Richard Rose, Public Perceptions of Threats to Security in Post-Communist Europe (Glasgow, Scotland: University of Strathclyde, Center for the Study of Public Policy, 1997), 6.

Government of the Republic of Bulgaria, National Security Concept (June 1999). Available from http://www.md.government.bg.

Government of the Republic of Bulgaria, Military Doctrine of the Republic of Bulgaria. (June 1999). Available from http://www.md.government.bg; INTERNET.

Haramiev-Drezov, Kyril, "Bulgarian-Russian Relations on a New Footing," RFE/RL Research Report 2, no. 15 (9 April, 1993): 33-38.

International Institute for Strategic Studies, The Military Balance (London: Oxford University Press, 1990), 84.

Jelavich, Barbara, History of the Balkans (New York: Cambridge University Press, 1983).

Ministry of Defense of the Republic of Bulgaria, Plan 2004 (June 2001). Available from http://www.md.government.bg; INTERNET

Ministry of Defense of the Republic of Bulgaria, Parliamentary Oversight and Democratic Control of the Bulgarian Armed Forces and Ministry of Defense, 
Tashev, Blagovest. A la búsqueda de la seguridad: la política de seguridad búlgara en transición.

study no. 3/1998 (June 1999). Available from http://www.md.government.bg; INTERNET.

Perry, Dunkan M., "New Directions for Bulgarian-Turkish Relations," RFE/RL Research Report 1, no. 41 (16 October, 1992): 33-40.

Rothschild, Joseph, Return to Diversity: A Political History of East Central Europe Since World War II (New York: Oxford University Press, 1993).

Simon, Jeffrey, "Bulgaria and NATO: 7 Lost Years," Strategic Forum no. 142 (May 1998). Available from http://www.ndu.edu.

Simon, Jeffrey, "Transforming the Armed Forces of Central and East Europe," Strategic Forum no. 172 (June 2000). Available from http://www.ndu.edu; Simon, "Bulgaria and NATO."

Slatinski, Nikolay and Marina Kaparini, "Bulgarian Security and Prospects for Reform." NATO Review no. 2 (March 1995): 28-32.

Srebrev, Michail, "Southern Europe: Concerns and Implications from a Bulgarian Perspective," in Charles L. Barry, ed., The Search for Peace in Europe: Perspectives from NATO and Eastern Europe (Fort Lesley: National Defense University Press, 1993). 